\title{
Invasive crayfish does not influence spawning microhabitat selection of brown frogs
}

\author{
Samuele Romagnoli ${ }^{\text {Corresp., }}{ }^{1}$, Gentile Francesco Ficetola ${ }^{1,2}$, Raoul Manenti ${ }^{1}$ \\ 1 Department of Environmental Science and Policy, University of Milan, Milan, Italy \\ 2 Laboratoire d'Ecologie Alpine (LECA), Université Grenoble-Alpes, Grenoble, France \\ Corresponding Author: Samuele Romagnoli \\ Email address: samuele.romagnoli@studenti.unimi.it
}

Microhabitat selection is a key component of amphibian breeding biology and can be modulated in response to the features of breeding sites and the presence of predators. Despite invasive alien species being among the major threats to amphibians, there is limited information on the role of invasive species in shaping amphibians' breeding microhabitat choice. The invasive red swamp crayfish (Procambarus clarkii) is a major predator of amphibians' larvae, including those of the brown frogs Rana dalmatina and Rana latastei. Although qualitative information about the spawning site preferences and breeding microhabitat choice of brown frogs is available in the literature, only a few studies performed quantitative analyses, and the relationship between microhabitat choice and the presence of alien predators has not been investigated yet. The aims of this study were: 1 ) to characterize the microhabitats selected for clutch deposition by $R$. dalmatina and $R$. latastei and 2 ) to test if the position and the aggregation of egg clutches differ in sites invaded or not invaded by P. clarkii. During spring 2017, we surveyed multiple times 15 breeding sites of both brown frogs in Northern Italy; in each site we assessed the features of the microhabitat where each egg clutch was laid, considering its position (distance from the shore, depth of the water column) and the degree of aggregation of clutches. In each site we also assessed the presence/absence of the invasive crayfish and the relative abundance in the breeding period. We detected egg clutches in all sites; the crayfish occurred in eight ponds. Our results showed substantial differences between the spawning microhabitat features of the two brown frogs: Rana latastei clutches showed a higher degree of aggregation and were associated with deeper areas of the ponds, while Rana dalmatina deposited more spaced out clutches in areas of the ponds that were less deep. For both species, spawning microhabitat features were not significantly different between sites with and without $P$. clarkii. Although we did not detect behavioural responses to $P$. clarkii in the choice of spawning microhabitat, additional studies are required to assess whether these frogs modulate other behavioural traits (e.g. during 
larval development) in response to the invasive predator. 
1 Invasive crayfish does not influence spawning microhabitat selection of brown frogs

2

3 Samuele Romagnoli $^{1 *}$, Gentile Francesco Ficetola ${ }^{1,2}$, Raoul Manenti $^{1}$

4

$5{ }^{1}$ Department of Environmental Science and Policy, University of Milan, Milan, Italy

$6 \quad{ }^{2}$ Laboratoire d'Ecologie Alpine (LECA), Université Grenoble-Alpes, Grenoble, France

7

8 * Corresponding author: Samuele Romagnoli

9 E-mail address: Samuele.romagnoli@studenti.unimi.it

10

11

12 


\section{Abstract}

14 Microhabitat selection is a key component of amphibian breeding biology and can be modulated

15 in response to the features of breeding sites and the presence of predators. Despite invasive alien

16 species being among the major threats to amphibians, there is limited information on the role of

17 invasive species in shaping amphibians' breeding microhabitat choice. The invasive red swamp

18 crayfish (Procambarus clarkii) is a major predator of amphibians' larvae, including those of the

19 brown frogs Rana dalmatina and Rana latastei. Although qualitative information about the

20 spawning site preferences and breeding microhabitat choice of brown frogs is available in the

21 literature, only a few studies performed quantitative analyses, and the relationship between

22 microhabitat choice and the presence of alien predators has not been investigated yet. The aims of

23 this study were: 1) to characterize the microhabitats selected for clutch deposition by R. dalmatina

24 and $R$. latastei and 2) to test if the position and the aggregation of egg clutches differ in sites

25 invaded or not invaded by P. clarkii. During spring 2017, we surveyed multiple times 15 breeding

26 sites of both brown frogs in Northern Italy; in each site we assessed the features of the microhabitat

27 where each egg clutch was laid, considering its position (distance from the shore, depth of the

28 water column) and the degree of aggregation of clutches. In each site we also assessed the

29 presence/absence of the invasive crayfish and the relative abundance in the breeding period. We

30 detected egg clutches in all sites; the crayfish occurred in eight ponds. Our results showed

31 substantial differences between the spawning microhabitat features of the two brown frogs: Rana

32 latastei clutches showed a higher degree of aggregation and were associated with deeper areas of

33 the ponds, while Rana dalmatina deposited more spaced out clutches in areas of the ponds that

34 were less deep. For both species, spawning microhabitat features were not significantly different

35 between sites with and without $P$. clarkii. Although we did not detect behavioural responses to $P$. 
36 clarkii in the choice of spawning microhabitat, additional studies are required to assess whether

37 these frogs modulate other behavioural traits (e.g. during larval development) in response to the 38 invasive predator.

39

\section{Keywords}

41 Alien, amphibians, behaviour, predation, breeding, clutch, egg 


\section{Introduction}

44 Amphibians are among the taxa with the highest ratio of threatened and declining species, and

45 their global decline has been the focus of many studies to quantify and understand the causes of 46 this phenomenon (Ficetola 2015; Scheele et al. 2019). The increase of trade and tourism all over

47 the world, which directly or indirectly facilitates the spread of alien animals and plants, is one of 48 the strongest threats to native biodiversity (Davis 2003), and amphibians are particularly sensitive 49 to the impact of alien species (Bellard et al. 2016). Invasive alien species (IAS) can have multiple 50 impacts on native amphibians. Predatory IAS can feed on both larvae and adults of many 51 amphibian species, spread diseases, and limit the trophic resources available (Fisher et al. 2009; 52 Hettyey et al. 2016; Kats \& Ferrer 2003), potentially leading to detrimental effects on the whole 53 ecosystem of the invaded sites (Jackson et al. 2016).

Adult amphibians are often able to detect the presence of predators and modulate their breeding activity to limit predation on their offspring. On the one hand, parents may actively select breeding sites with few predators, and this has been shown to increase offspring fitness (Resetarits 2005; Sadeh et al. 2009; Segev et al. 2011; Winandy et al. 2015). The selection of breeding sites with few predators can also frequent in amphibians that stay in water for very short periods, and that can detect predators through indirect cues (e.g. chemical cues) (Resetarits 2005). On the other hand, breeding sites without predators are not always available, and similarity of habitat preferences between amphibians and their predators may force the former to breed in sites with

62 predators. However, wetlands can be very heterogeneous environments with a high number of 63 microhabitats. Within a given breeding wetland the density of predators and predation risk can 64 vary across microhabitats, thus females can select specific sites to increase the survival of tadpoles 65 (Ficetola et al. 2006). However, up to now very few studies have investigated whether amphibians 
66 change their patterns of microhabitat selection in response to invasive predators. both in Europe and on a global scale (Nentwig et al. 2018). This crayfish is a generalist feeder 69 (Alcorlo et al. 2004; Whitledge \& Rabeni 1997), and its global spread affects a growing number of freshwater communities worldwide (Cruz et al. 2008; Ficetola et al. 2011b; Manenti et al. 71 2019b; Ramamonjisoa et al. 2018; Vilà et al. 2010). P. clarkii preys on tadpoles of several amphibian species (Cruz et al. 2008); in northern Italy crayfish predation is a major cause of local extinctions and tadpole abundances reduction (Ficetola et al. 2011b). The strong predation of $P$. clarkii on frog tadpoles may drive rapid behavioural or evolutionary responses in invaded communities (Nunes et al. 2014a; Nunes et al. 2014b); on the other hand, when there is a lack of anti-predatory response to this invasive crayfish, there is a high risk of extinction of amphibian populations (Nunes et al. 2013). The negative relationship between P. clarkii and tadpole abundance is particularly evident for some brown frog species, such as the agile frog (Rana dalmatina) and the Italian agile frog (Rana latastei) (Ficetola et al. 2011b). Although these two species of brown frogs often breed in sites invaded by $P$. clarkii, a study performed a few years after the invasion showed that very few tadpoles reach metamorphosis in wetlands with high crayfish density (Ficetola et al. 2011b). Rana dalmatina and R. latastei are species of conservation concern, and their tadpoles can be the most abundant vertebrates in small wetlands, thus they likely

84 allow a substantial exchange of biomass from woody parches to the ponds in which they breed and 85 vice-versa (Barzaghi et al. 2017; Gibbons et al. 2006).

To assess whether $R$. dalmatina and $R$. latastei can modulate microhabitat selection in

87 presence of invasive predators, we tested three hypotheses. 1) Shelter hypothesis. Along the shore, 88 riparian semi-aquatic vegetation, submerged branches and hiding elements are more abundant and 
89 can offer shelter from aquatic predators (Dodd 2010; Ficetola et al. 2006; Manenti et al. 2017).

90 Therefore, if the shelter hypothesis is correct, we expect that in invaded ponds, frogs lay clutches

91 closer to the pond edge.

92 2) Deepness hypothesis. The crayfish is rarely active in the water column, thus laying 93 clutches in deep water can reduce predation rate on eggs and tadpoles (Cruz \& Rebelo 2005).

94 Therefore, this hypothesis predicts that, in invaded sites, frogs lay clutches in deeper water.

3) Schooling hypothesis. When tadpoles hatch, they show high local density during their most vulnerable stage; thus, by laying clutches nearby other clutches, frogs can form large assemblages of clutches and tadpoles. This grouping strategy can provide advantages under high predation risk (e.g. confusion, enhanced group vigilance, diluted predation risk (Lima \& Dill 1990; Nicieza 1999). If the schooling hypothesis is right, we expect to find less distance between clutches in invaded wetlands.

To achieve our aims we first characterized the features of the microhabitats selected by the two frogs; the spawning habits and the microhabitat selection of these two species have been described in the literature, but quantitative analyses remain limited (Ancona \& Capietti 1996; Ficetola et al. 2006). We then tested if there was significant variation in spawning features between invaded and non-invaded sites.

\section{Materials and Methods}

108 In spring 2017, we surveyed 15 breeding sites in northern Italy for which previous surveys 109 confirmed the reproduction of at least one brown frog species (R. latastei or R. dalmatina). All the

110 wetlands were in the basin of two tributaries of the Po river, Lambro and Adda rivers, north of

111 Milan. Since the early 2000s, wetlands of the Po lowland have been invaded by P. clarkii (Fea et 
112 al. 2006) that was first detected in our study area around 2005 (Manenti et al. 2014). Since 2005,

113 P. clarkii spread in the study area colonising approx. $65 \%$ of the permanent, large ponds that

114 generally constitute the breeding sites of these frogs (Manenti et al. 2014; Manenti et al. 2019a).

115 The crayfish impact is heterogeneous across sub-populations (Manenti et al. 2019a; Siesa et al.

116 2011). Previous studies have shown $P$. clarkii exerts a heavy predation pressure on the larvae of

$117 R$. latastei and $R$. dalmatina, strongly reducing their abundance, and that the impact of crayfish

118 predation is stronger than the effects of native predators such as dragonflies (Ficetola et al. 2012).

119 In both frog species, the deposition period begins in early spring and each female lays only

120 one clutch. The detectability of clutches is high and the two species can be identified based on of

121 their morphological characteristics (Ambrogio \& Mezzadri 2018). For each site, we performed

122 two surveys at the peak of frog breeding activity (March), one during daytime and one during the

123 night. During daytime surveys, we assessed the features of the microhabitat of deposition of each

124 egg clutch of $R$. latastei and $R$. dalmatina. For each clutch we measured three variables describing

125 the position and the degree of aggregation of clutches: distance from the pond shore, interclutch

126 distance (distance from the closest conspecific clutch), and depth of the water column. We

127 measured the distance from the pond shore as the minimum distance between the clutch and the

128 closest edge of the breeding site. In the study ponds, aquatic vegetation was nearly absent, while

129 semi-aquatic vegetation and submerged branches were most abundant near the shoreline, thus

130 distance from the pond shore is a good proxy of the availability of shelters for tadpoles. To assess

131 interclutch distance, for each clutch we identified the closest conspecific clutch and measured the

132 distance between them. When two clutches were in contact, the distance was recorded as zero. We

133 measured depth of the water column as the total depth of the water column at the spawning point,

134 also if the clutch was underwater (as often occurs for $R$. latastei). Moreover, we measured the 
135 maximum depth and the surface of each wetland to compare pond features among invaded and not

136 invaded sites. The total number of clutches per site and surface was then used to calculate clutch

137 density at each breeding site. A few clutches were clearly laid several days before sampling, and,

138 especially for the agile frog, drift could have modified their position; for this reason, they were not 139 considered for microhabitat measurements.

140 To verify the occurrence of the red swamp crayfish and to measure the relative abundance

141 of crayfishes in ponds active during the breeding period, we performed one visual encounter survey

142 during night-time to maximize the detection probability of the crayfish. Recent studies showed

143 that during nocturnal surveys the per-visit detection probability is very high ( $>95 \%$; Manenti et al.

144 2019b). Surveys were performed using night lamps along the whole perimeter of the ponds and

145 lightening the inner sectors as much as possible.

146 Invasive species often have the strongest impacts on sites where they attain the highest abundance

147 (Leung et al. 2012). In this case, just measuring the presence/absence of invasives can obscure

148 patterns caused by variation of abundance. Therefore we estimated relative abundance of

149 crayfishes across sites during breeding period using CPUE (Catch Per Unit Effort) index

150 (Zimmerman \& Palo 2011)applying the following formula:

$$
\text { CPUE }=\frac{N_{\text {crayfish }}}{m \times t \times \mathrm{N}_{\mathrm{obs}}}
$$

152 where " $\mathrm{N}$ crayfish" is the number of individuals observed, " $\mathrm{m}$ " is the distance travelled during the

153 survey, " $t$ " the time spent in the survey and " $N_{\text {obs" }}$ the number of observers participating in the

154 survey (Anderson et al. 2015).

156 Total survey time was proportional to the surface of ponds and considered in the calculation of the

157 CPUE index. Particular attention was paid to the occurrence of small young individuals. Additional 
158 surveys were performed in the same sites during the late spring - middle summer of 2017 and

1592019 and confirmed the absence of alien crayfish detection in the sites considered as non-invaded

160 during this study (Manenti et al. 2019b). For only one pond we don't have data of relative

161 abundance of crayfish.

162

163 Statistical Analyses

164 Before running analyses, interclutch distance, clutch density, distance from the shore and CPUE

165 index were log-transformed, while water depth was square-root transformed to improve normality.

166 First, we used t-tests, assuming heterogeneous variance, to assess whether pond features (pond

167 surface, maximum depth and clutch density) were significantly different between invaded and non-

168 invaded ponds. Then, we used linear mixed models (LMMs) to assess whether the study species

169 select different microhabitat features. We ran three separate LMMs with the different dependent

170 variables (distance from pond edge, interclutch distance and water depth) and with species identity

171 as the independent variable; the site was included as a random factor to take into account the non-

172 independence of clutches within the same site.

173 Finally, we tested whether spawning site selection is different between invaded and non-

174 invaded sites. Given that we generally found differences in microhabitat selection between the two

175 frog species (see results), we analysed them separately. For each species, we used LMMs to assess

176 whether distance from the shore, interclutch distance and water depth are significantly different

177 between invaded and non-invaded sites. For the analysis of water depth, we included the maximum

178 water depth in each pond as a covariate; for the analysis concerning distance from the shore and

179 interclutch distance we included clutch density as a covariate. In some cases, the variance of

180 dependent variables showed heteroscedasticity between groups ( $R$. dalmatina vs. $R$. latastei 
181 clutches; invaded vs non-invaded sites; see supplementary materials for details). Therefore, we

182 compared LMMs assuming homogeneous variance with models assuming heterogeneous variance

183 between invaded and non-invaded sites. Models were fit using the VarIdent argument of the lmer

184 function in R (Pinheiro \& Bates 2000). We used a likelihood ratio test to assess if the model

185 assuming heterogeneous variance performed significantly better than the one with homogeneous

186 variance. The model with heterogeneous variance was then used since it provided a significantly

187 better fit. We used a likelihood ratio test to evaluate whether the model with heterogeneous

188 variance better fit the data. This analysis was also repeated for each frog species using crayfish

189 relative abundance (CPUE) instead of occurrence/absence as an independent variable (we

190 excluded one breeding site of R.dalmatina because we didn't have data of abundance of crayfish).

191 This allowed us to test the robustness of our conclusion to variation of crayfish abundance across 192 ponds.

193 Analyses were performed in environment R using the packages "lme4" (Bates et al. 2015) and

194 "nlme” (Pinheiro et al. 2016; RDevelopment 2010).

195

\section{Results}

197 Overall, we measured spawning site features for 498 clutches of the two frog species (333 $R$.

198 dalmatina and 165 R. latastei clutches) in the 15 surveyed sites. Ponds showed an average ( \pm SD)

199 surface of $94.6 \pm 87.1 \mathrm{~m}^{2}$, a maximum depth in average $( \pm \mathrm{SD})$ of $48.9 \pm 24.7 \mathrm{~cm}$. We detected

200 the red swamp crayfish in eight sites. Regarding Rana dalmatina, we detected clutches in 13 sites,

2016 uninvaded and 7 invaded by crayfish, with a mean ( \pm SD) number of clutches per site of $26 \pm 7$.

202 For Rana latastei we detected clutches in 8 waterbodies, 6 uninvaded and 2 invaded (average: 21

$203 \pm 8$ clutches per site). Ponds invaded and non-invaded by $P$. clarkii showed similar environmental 
204 variables. There were no significant differences for pond surface $\left(t_{9.2}=2.05, P=0.07\right)$, max depth $205\left(\mathrm{t}_{11}=-1.46, \mathrm{P}=0.17\right)$, or for clutch density of the two frog species $\left(\right.$ R. latastei: $\mathrm{t}_{6.20}=-0.75, \mathrm{P}=$

$2060.48, R$. dalmatina: $\mathrm{t}_{12.4}=-1.05, \mathrm{P}=0.31$ ). The CPUE index (abundance) of $P$. clarkii was generally 207 low with a mean of $0.02 \pm 0.03$ ( $\mathrm{N}$ crayfish / meters * minutes * $\mathrm{N}$ observers) for R. dalmatina 208 breeding sites and $0.008 \pm 0.02$ for $R$. latastei breeding sites.

210 Spawning microhabitat differences between $R$. dalmatina and R. latastei

211 Rana latastei clutches were more grouped than the $R$. dalmatina ones. The average interclutch

212 distance $( \pm \mathrm{SD})$ was $24.7 \pm 34.1 \mathrm{~cm}$ for $R$. latastei, and $98.3 \pm 122.3 \mathrm{~cm}$ for $R$. dalmatina $\left(\mathrm{F}_{1,482}=\right.$

213 29.1; P < 0.001; Fig.1a). Furthermore, R. latastei clutches were laid in deeper sectors of ponds

214 than $R$. dalmatina $\left(\mathrm{F}_{1,482}=5.33 ; \mathrm{P}=0.02\right.$; Fig. $\left.1 \mathrm{~b}\right)$; the mean depth $( \pm \mathrm{SD})$ of water column was

$21522.8 \pm 7.8 \mathrm{~cm}$ for $R$. latastei clutches while it was $18.5 \pm 6.8 \mathrm{~cm}$ for $R$. dalmatina clutches. $R$.

216 latastei also laid clutches more distant from the shore of the pond than $R$. dalmatina $\left(\mathrm{F}_{1,482}=4.16\right.$

$217 ; \mathrm{P}=0.04$; Fig. 1c); the mean $( \pm \mathrm{SD})$ distance between the shore and $R$. latastei egg-clutches was

$218164.6 \pm 201.6 \mathrm{~cm}$, while it was $131.4 \pm 101.8 \mathrm{~cm}$ for $R$. dalmatina clutches.

Clutch microhabitat features in invaded and non-invaded sites

221 For both frog species, the spawning microhabitat features were similar between invaded and non-

222 invaded ponds (Table 1). We did not detect any significant relationship between crayfish

223 occurrence and microhabitat neither regarding the distance between the clutches, nor the depth of

224 the water column, nor the distance from the pond edge. Results were identical when we consider

225 the variation of crayfish abundance, as we did not detect any significant relationship between

226 crayfish CPUE and spawning microhabitat features (Table 2). 


\section{Discussion}

229 The differences observed between Rana latastei and $R$. dalmatina highlight the importance of

230 microhabitat selection for these frog species that adopt different strategies and select different

231 spawning sites. Nevertheless, we did not detect any relationship between the spawning

232 microhabitat choice and the occurrence of the alien predator Procambarus clarkii. Our results did

233 not conform with the predictions of either the shelter, the deepness or the schooling hypothesis,

234 suggesting that the choice of the spawning position by adults is not modulated to minimize

235 predation risk of eggs and tadpoles by the alien crayfish.

236 There are many reported cases of dramatic effects of alien species introduction on native

237 species, which range from behavioural shifts of native species (Tiberti \& von Hardenberg 2012;

238 Winandy \& Denoël 2013) to cascading effects on entire ecosystems, and can lead to the extirpation

239 of entire species or communities (Arribas et al. 2014; Bonelli et al. 2017). Semi-aquatic organisms

240 like amphibians can play important roles for nutrient exchanges between aquatic and terrestrial

241 habitats (Barzaghi et al. 2017; Gibbons et al. 2006), thus invasive crayfish is expected to deeply

242 affect the biotic community of both lentic and lotic environments (Ficetola et al. 2012; Ficetola et

243 al. 2011b; Gherardi \& Acquistapace 2007; Manenti et al. 2019b; Shin-ichiro et al. 2009). If the

244 breeding microhabitat selected by adult amphibians is important for their breeding success, we

245 expect a modulation of habitat choice in response to the presence of IAS. Evolutionary and plastic

246 changes in invaded communities can arise at different levels and might be difficult to detect (Nunes

247 et al. 2014a). In our study area, previous research detected brown frogs breeding in sites with red

248 swamp crayfish (Ficetola et al. 2011b). Given the high tadpole mortality in invaded wetlands, a

249 plastic selection of breeding habitats and microhabitats could limit predation on eggs or tadpoles. 
250 However, adult brown frogs have continued to breed for several years in these ponds, selecting the

251 same microhabitat features as in non-invaded waterbodies. This suggests that, contrary to what

252 happens in urodeles (Cabrera-Guzman et al. 2019; Winandy et al. 2017), predation pressure of the

253 alien crayfish does not lead to rapid shifts or responses in adult brown frogs spawning behaviour.

254 The ability of native prey to assess risk and adopt appropriate behavioural responses

255 depends on different factors such as the experience accumulated during the lifespan, their learning

256 ability and also their evolutionary history and ecology (Kovacs et al. 2012). Several factors can

257 explain the lack of microhabitat shifts in brown frogs. First, contrary to urodeles that invest

258 considerable time in courtship and eggs laying, brown frogs invest relatively little time in egg-

259 laying, and frogs remain in breeding wetlands from few hours to at maximum one day (Ambrogio

260 \& Mezzadri 2018). Such a period can be too short to allow them to acquire enough experience on

261 the risk determined by the red swamp crayfish occurrence. Nevertheless, it is important to remark

262 that multiple studies evidenced that amphibians can detect predator chemical cues in water, and

263 can modulate the breeding habitat selection even when they use breeding sites for few hours

264 (Resetarits 2005; Sadeh et al. 2009). Second, brown frogs breed at the end of winter, when water

265 temperatures are low. The activity of the red swamp crayfish is generally high during warm periods

266 (Holdich et al. 2009); thus, the individuals may not be particularly active when adult frogs are in

267 the water, with limited consumptive effects. The worst effect of the crayfish probably happens

268 only later in the season when temperatures rise, and the crayfish mostly impacts the tadpoles.

269 Third, it is possible that the time since the arrival of the red swamp crayfish was not enough for

270 frog populations to develop appropriate antipredator adaptations. Recent studies show that even if

271 the ability to recognise invasive predators may evolve quickly, agile frog populations can be

272 vulnerable to alien fish due to their inability to recognize them as a threat (Hettyey et al. 2016). 

predator (Sih et al. 2010). The first detection of the red swamp crayfish in the study area dates back to 2005 (Manenti et al. 2014), indicating that frogs coexisted with the crayfish for approx. 3-4 generations (Guarino et al. 2003; Racca 2003; Weddeling et al. 2005). Rapid local adaptations of brown frogs when selective pressure is strong are known (Ficetola et al. 2011a; Skelly \& Freidenburg 2000), still amphibians responses to invasive species are mostly known to occur at 279 the tadpole stage (Hettyey et al. 2016; Nunes et al. 2014b; Nunes et al. 2013). Future studies are required to investigate if behavioural responses may occur in the larval stages of the study species.

281 We should also underline that, especially for $R$. latastei, the number of uninvaded ponds was low,

282 because the crayfish has already invaded most breeding sites of this frog. To confirm the generality 283 of our results it would be thus interesting to increase the number of uninvaded breeding sites, for 284 instance in regions where $P$. clarkii is less widespread.

\section{Conclusion}

Our study characterized the spawning microhabitat of the agile frog and the Italian agile frog, considering also sites in which they are syntopic and quantifying differences in spawning microhabitat between these two species. Italian agile frog females lay eggs in significantly deeper areas of the ponds, and with a strongly aggregated pattern. The clustering of Italian agile frog clutches has been repeatedly described in the herpetological literature, and it is known that dozens of females can attach their egg-clutches to the same submerged woods (Ambrogio \& Mezzadri 2018; Pozzi 1980). However, there are few data on the causes of microhabitat selection. First, differences in microhabitat could reduce the frequency of interactions with heterospecific males, 
296 2003; Hettyey et al. 2014). Second, tadpoles could exploit different microhabitats within the

297 wetlands, for instance because they have different thermal optima (Balogová \& Gvoždík 2015).

298 Nevertheless, very limited information exists so far on differences in microhabitat use between

299 tadpoles, and future studies are required to understand the factors allowing the syntopy between

300 these frog species, and the relative effect of micro and macro-ecological determinants. A better

301 knowledge of behaviour of these species is an important starting point for a better understanding

302 of the strategies of these animals in response to biological invasions.

303 The invasive crayfish is widespread in the study area (Manenti et al. 2019a; Manenti et al.

304 2019b) and is likely to attain high density, making eradication programs almost impossible. Under

305 these circumstances, it is essential to identify the processes that can allow long-term persistence

306 of native species, such as behavioural changes or the selection of specific microhabitats. However,

307 such processes can be complex and can occur at multiple levels, and this can make their

308 identification challenging. On the one hand, it will be important to integrate analysis performed on

309 the microhabitat-scale with research performed on the landscape level, with long term analysis

310 including the metapopulation-scale (Manenti et al. 2019a). On the other hand, additional studies

311 are required to assess whether native frogs can modulate other behavioural traits when interactions

312 with the crayfish are more frequent, such as during larval development.

\section{ACKNOWLEDGMENTS}

315 We thank Pietro Leotta, Vito Leotta, F. Maurizio, P. Togni and S. Fumagalli for different linguistic

316 revisions of the manuscript. The comments of the editor Claire Paris and two anonymous reviewers

317 greatly improved an early draft of the manuscript. 


\section{References}

319 Alcorlo P, Geiger W, and Otero M. 2004. Feeding preferences and food selection of the red

320

321

322

323

324

325

326

327

328

329

330

331

332

333

334

335

336

337

338

339

340

341

342

343

344

345

346

347

348

349

350

351

352

353

354

355

356

357

358

359

360

361 swamp crayfish, Procambarus clarkii, in habitats differing in food item diversity. Crustaceana International Journal of Crustacean Research 77:435-454.

Ambrogio A, and Mezzadri S. 2018. Rane rosse d'Italia - Brown frogs of Italy. Piacenza: Gavia Edizioni.

Ancona N, and Capietti A. 1996. Osservazioni sulla disposizione di uova e girini di Rana temporaria e $R$. dalmatina in un'area prealpina: [Museo tridentino di scienze naturali](IS).

Anderson N, Paszkowski C, and Hood G. 2015. Linking aquatic and terrestrial environments: can beaver canals serve as movement corridors for pond-breeding amphibians? Animal Conservation 18:287-294.

Arribas R, Díaz-Paniagua C, and Gomez-Mestre I. 2014. Ecological consequences of amphibian larvae and their native and alien predators on the community structure of temporary ponds. Freshwater Biology 59:1996-2008.

Balogová M, and Gvoždík L. 2015. Can Newts Cope with the Heat? Disparate Thermoregulatory Strategies of Two Sympatric Species in Water. PloS one 10:e0128155. 10.1371/journal.pone.0128155

Barzaghi B, Ficetola GF, Pennati R, and Manenti R. 2017. Biphasic predators provide biomass subsidies in small freshwater habitats: A case study of spring and cave pools. Freshwater Biology 62:1637-1644.

Bates D, Maechler M, Bolker B, and Walker S. 2015. Fitting linear mixed-effects models using lme4. Journal of Statistical Software 67 (1): 1-48.

Bellard C, Cassey P, and Blackburn TM. 2016. Alien species as a driver of recent extinctions. Biology letters 12:20150623.

Bonelli M, Manenti R, and Scaccini D. 2017. Mountain protected areas as refuges for threatened freshwater species: the detrimental effect of the direct introduction of alien species. eco mont-Journal on Protected Mountain Areas Research 9:23-29.

Cabrera-Guzman E, Diaz-Paniagua C, and Gomez-Mestre I. 2019. Invasive mosquitofish (Gambusia holbrooki) affect egg-laying and behaviour of Spanish pygmy newts (Triturus pygmaeus). Amphibia-Reptilia 40:103-112.

Cruz M, Segurado P, Sousa M, and Rebelo R. 2008. Collapse of the amphibian community of the Paul do Boquilobo Natural Reserve (central Portugal) after the arrival of the exotic American crayfish Procambarus clarkii. The Herpetological Journal 18:197-204.

Cruz MJ, and Rebelo R. 2005. Vulnerability of Southwest Iberian amphibians to an introduced crayfish, Procambarus clarkii. Amphibia-Reptilia 26:293-303.

$10.1163 / 156853805774408577$

Davis MA. 2003. Biotic globalization: does competition from introduced species threaten biodiversity? BioScience 53:481-489.

Dodd CK. 2010. Amphibian ecology and conservation: a handbook of techniques: Oxford University Press.

Fea G, Nardi PA, Ghia D, Spairani M, Manenti R, Rossi S, Moroni M, and Bernini F. 2006. Dati preliminari sulla distribuzione in Lombardia dei gamberi d'acqua dolce autoctoni e alloctoni. Atti Soc It Sci Nat Mus Civ St Nat Milano 147:201-210. 
362 Ficetola G, Valota M, and De Bernardi F. 2006. Temporal variability of spawning site selection

363

364

365

366

367

368

369

370

371

372

373

374

375

376

377

378

379

380

381

382

383

384

385

386

387

388

389

390

391

392

393

394

395

396

397

398

399

400

401

402

403

404

405 in the frog Rana dalmatina: consequences for habitat management. Animal biodiversity and conservation 29:157-163.

Ficetola GF. 2015. Habitat conservation research for amphibians: methodological improvements and thematic shifts. Biodiversity and Conservation 24:1293-1310.

Ficetola GF, and Bernardi FD. 2005. Interspecific social interactions and breeding success of the frog Rana latastei: a field study. Ethology 111:764-774.

Ficetola GF, Garner TWJ, Wang J, and De Bernardi F. 2011a. Rapid selection against inbreeding in a wild population of a rare frog. Evolutionary Applications 4:30-38. 10.1111/j.17524571.2010.00130.x

Ficetola GF, Siesa ME, De Bernardi F, and Padoa-Schioppa E. 2012. Complex impact of an invasive crayfish on freshwater food webs. Biodiversity and Conservation 21:2641-2651.

Ficetola GF, Siesa ME, Manenti R, Bottoni L, De Bernardi F, and Padoa-Schioppa E. 2011 b. Early assessment of the impact of alien species: differential consequences of an invasive crayfish on adult and larval amphibians. Diversity and Distributions 17:1141-1151.

Fisher MC, Garner TW, and Walker SF. 2009. Global emergence of Batrachochytrium dendrobatidis and amphibian chytridiomycosis in space, time, and host. Annual review of microbiology 63:291-310.

Gherardi F, and Acquistapace P. 2007. Invasive crayfish in Europe: the impact of Procambarus clarkii on the littoral community of a Mediterranean lake. Freshwater Biology 52:12491259.

Gibbons JW, Winne CT, Scott DE, Willson JD, Glaudas X, Andrews KM, Todd BD, Fedewa LA, Wilkinson L, and Tsaliagos RN. 2006. Remarkable amphibian biomass and abundance in an isolated wetland: implications for wetland conservation. Conservation Biology 20:1457-1465.

Guarino FM, Lunardi S, Carlomagno M, and Mazzotti S. 2003. A skeletochronological study of growth, longevity, and age at sexual maturity in a population of Rana latastei (Amphibia, Anura). Journal of biosciences 28:775-782.

Hettyey A, and Pearman PB. 2003. Social environment and reproductive interference affect reproductive success in the frog Rana latastei. Behavioral Ecology 14:294-300.

Hettyey A, Thonhauser KE, Bókony V, Penn DJ, Hoi H, and Griggio M. 2016. Naive tadpoles do not recognize recent invasive predatory fishes as dangerous. Ecology 97:2975-2985.

Hettyey A, Vági B, Kovács T, Ujszegi J, Katona P, Szederkényi M, Pearman PB, Griggio M, and Hoi H. 2014. Reproductive interference between Rana dalmatina and Rana temporaria affects reproductive success in natural populations. Oecologia 176:457-464.

Holdich D, Reynolds J, Souty-Grosset C, and Sibley P. 2009. A review of the ever-increasing threat to European crayfish from non-indigenous crayfish species. Knowledge and management of aquatic ecosystems: 11 .

Jackson MC, Loewen CJ, Vinebrooke RD, and Chimimba CT. 2016. Net effects of multiple stressors in freshwater ecosystems: a meta-analysis. Global change biology 22:180-189.

Kats LB, and Ferrer RP. 2003. Alien predators and amphibian declines: review of two decades of science and the transition to conservation. Diversity and Distributions 9:99-110.

Kovacs EK, Crowther MS, Webb JK, and Dickman CR. 2012. Population and behavioural responses of native prey to alien predation. Oecologia 168:947-957.

Peer] reviewing PDF | (2019:05:37953:3:1:NEW 13 Mar 2020) 
406

407

408

409

410

411

412

413

414

415

416

417

418

419

420

421

422

423

424

425

426

427

428

429

430

431

432

433

434

435

436

437

438

439

440

441

442

443

444

445

446

447

448

449

450

451

Leung B, Roura-Pascual N, Bacher S, Heikkilä J, Brotons L, Burgman MA, Dehnen-Schmutz K, Essl F, Hulme PE, and Richardson DM. 2012. Teasing apart alien species risk assessments: a framework for best practices. Ecology letters 15:1475-1493.

Lima SL, and Dill LM. 1990. Behavioral decisions made under the risk of predation: a review and prospectus. Canadian journal of zoology 68:619-640.

Manenti R, Bonelli M, Scaccini D, Binda A, and Zugnoni A. 2014. Austropotamobius pallipes reduction vs. Procambarus clarkii spreading: Management implications. Journal for Nature Conservation 22:586-591. 10.1016/j.jnc.2014.09.001

Manenti R, Falaschi M, Delle Monache D, Marta S, and Ficetola GF. 2019a. Network-scale effects of invasive species on spatially-structured amphibian populations. Ecography.

Manenti R, Ghia D, Fea G, Ficetola GF, Padoa-Schioppa E, and Canedoli C. 2019b. Causes and consequences of crayfish extinction: Stream connectivity, habitat changes, alien species and ecosystem services. Freshwater Biology 64:284-293.

Manenti R, Zanetti N, Pennati R, and Scarì G. 2017. Factors driving semi-aquatic predator occurrence in traditional cattle drinking pools: conservation issues. Journal of limnology 76.

Nentwig W, Bacher S, Kumschick S, Pyšek P, and Vilà M. 2018. More than "100 worst” alien species in Europe. Biological Invasions 20:1611-1621.

Nicieza A. 1999. Context-dependent aggregation in Common Frog Rana temporaria tadpoles: influence of developmental stage, predation risk and social environment. Functional Ecology 13:852-858.

Nunes AL, Orizaola G, Laurila A, and Rebelo R. 2014a. Morphological and life-history responses of anurans to predation by an invasive crayfish: An integrative approach. Ecology and evolution 4:1491-1503.

Nunes AL, Orizaola G, Laurila A, and Rebelo R. 2014b. Rapid evolution of constitutive and inducible defenses against an invasive predator. Ecology 95:1520-1530.

Nunes AL, Richter-Boix A, Laurila A, and Rebelo R. 2013. Do anuran larvae respond behaviourally to chemical cues from an invasive crayfish predator? A community-wide study. Oecologia 171:115-127.

Pinheiro J, Bates D, DebRoy S, and Sarkar D. 2016. R Core Team. nlme: Linear and nonlinear mixed effects models. R package version 3.1-128. 2016.

Pinheiro JC, and Bates DM. 2000. Linear mixed-effects models: basic concepts and examples. Mixed-effects models in S and S-Plus:3-56.

Pozzi A. 1980. Ecologia di Rana latastei Boulenger:(Amphibia Anura): Fusi (stamp.).

Racca L. 2003. Conservation of the Agile Frog — the Rarest Amphibian in the British Isles? Herpetologica petropolitana:205.

Ramamonjisoa N, Rakotonoely H, and Natuhara Y. 2018. Differential vulnerability of two sympatric tadpoles to an invasive crayfish predator. Hydrobiologia 818:119-127.

RDevelopment C. 2010. TEAM 2011: R: A language and environment for statistical computing. R Foundation for Statistical Computing. Internetseite (abgerufen am 1202 2012): http://www R-project org.

Resetarits WJ. 2005. Habitat selection behaviour links local and regional scales in aquatic systems. Ecology letters 8:480-486.

Sadeh A, Mangel M, and Blaustein L. 2009. Context-dependent reproductive habitat selection: the interactive roles of structural complexity and cannibalistic conspecifics. Ecology letters 12:1158-1164. 
452

453

454

455

456

457

458

459

460

461

462

463

464

465

466

467

468

469

470

471

472

473

474

475

476

477

478

479

480

481

482

483

484

485

486

487

488

489

490

491

492
Scheele BC, Pasmans F, Skerratt LF, Berger L, Martel A, Beukema W, Acevedo AA, Burrowes PA, Carvalho T, and Catenazzi A. 2019. Amphibian fungal panzootic causes catastrophic and ongoing loss of biodiversity. Science 363:1459-1463.

Segev O, Mangel M, Wolf N, Sadeh A, Kershenbaum A, and Blaustein L. 2011. Spatiotemporal reproductive strategies in the fire salamander: a model and empirical test. Behavioral Ecology 22:670-678.

Shin-ichiro SM, Usio N, Takamura N, and Washitani I. 2009. Contrasting impacts of invasive engineers on freshwater ecosystems: an experiment and meta-analysis. Oecologia 158:673-686.

Siesa ME, Manenti R, Padoa-Schioppa E, De Bernardi F, and Ficetola GF. 2011. Spatial autocorrelation and the analysis of invasion processes from distribution data: a study with the crayfish Procambarus clarkii. Biological Invasions 13:2147-2160.

Sih A, Bolnick DI, Luttbeg B, Orrock JL, Peacor SD, Pintor LM, Preisser E, Rehage JS, and Vonesh JR. 2010. Predator-prey naïveté, antipredator behavior, and the ecology of predator invasions. Oikos 119:610-621.

Skelly DK, and Freidenburg LK. 2000. Effects of beaver on the thermal biology of an amphibian. Ecology letters 3:483-486. 10.1111/j.1461-0248.2000.00186.x

Tiberti R, and von Hardenberg A. 2012. Impact of introduced fish on common frog (Rana temporaria) close to its altitudinal limit in alpine lakes. Amphibia-Reptilia 33:303-307.

Vilà M, Basnou C, Pyšek P, Josefsson M, Genovesi P, Gollasch S, Nentwig W, Olenin S, Roques A, and Roy D. 2010. How well do we understand the impacts of alien species on ecosystem services? A pan-European, cross-taxa assessment. Frontiers in Ecology and the Environment 8:135-144.

Weddeling K, Bosbach G, Hatchel M, Sander U, Schmidt P, and Tarkhnishvili D. 2005. Egg Size Versus Clutch Size: variation and trade-offs in reproductive output of Rana dalmatina and R. temporaria in a pond near Bonn (Germany)(In: Proceedings of the 12th Ordinary General Meeting of the Societas Europaea Herpetologica, Eds: N. Ananjeva, O. Tsinenko)-Societas Europaea Herpetol. St Petersburg:238-240.

Whitledge GW, and Rabeni CF. 1997. Energy sources and ecological role of crayfishes in an Ozark stream: insights from stable isotopes and gut analysis. Canadian Journal of Fisheries and Aquatic Sciences 54:2555-2563.

Winandy L, Darnet E, and Denoël M. 2015. Amphibians forgo aquatic life in response to alien fish introduction. Animal behaviour 109:209-216.

Winandy L, and Denoël M. 2013. Cues from introduced fish alter shelter use and feeding behaviour in adult alpine newts. Ethology 119:121-129.

Winandy L, Legrand P, and Denoël M. 2017. Habitat selection and reproduction of newts in networks of fish and fishless aquatic patches. Animal behaviour 123:107-115.

Zimmerman JK, and Palo R. 2011. Reliability of catch per unit effort (CPUE) for evaluation of reintroduction programs-A comparison of the mark-recapture method with standardized trapping. Knowledge and management of aquatic ecosystems:07. 
Figure 1

Differences between species

Partial regression plots of models showing differences in clutch microhabitat features between Rana latastei and $R$. dalmatina. 

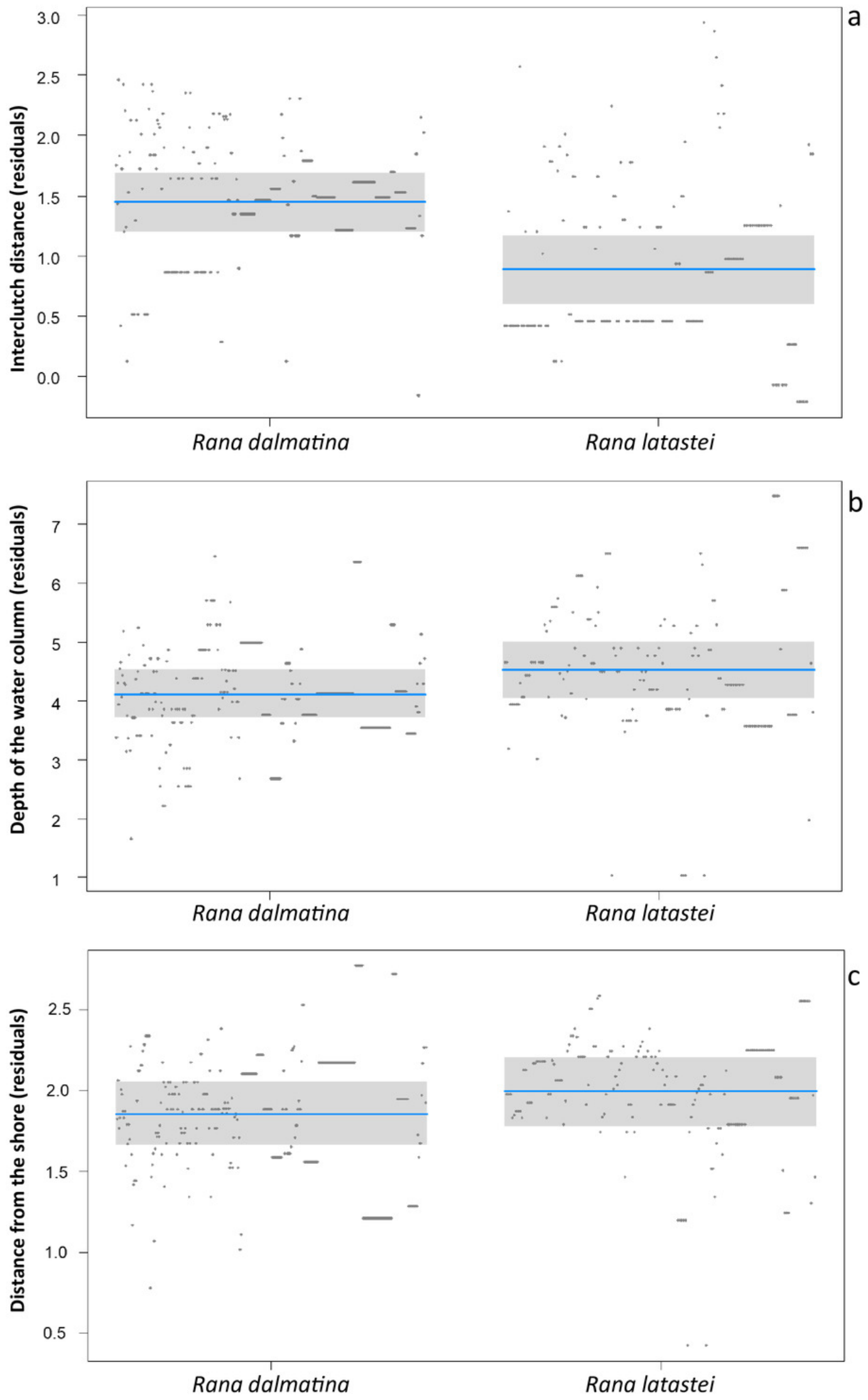


\section{Table $\mathbf{1}$ (on next page)}

Clutch microhabitat features in invaded and non invaded.

Clutch microhabitat features in invaded and non invaded sites for each species. Mean values for each microhabitat features are expressed in $\mathrm{cm} \pm \mathrm{SD}$. 


\begin{tabular}{|c|c|c|c|c|c|c|}
\hline \multirow[t]{3}{*}{ Dependent } & \multirow[t]{3}{*}{ Independent } & \multicolumn{5}{|c|}{ Rana latastei } \\
\hline & & Without crayfish & With crayfish & df & $\mathrm{F}$ & $P$ \\
\hline & & Mean & Mean & & & \\
\hline \multirow[t]{3}{*}{ Interclutch distance } & & $\begin{array}{l}10.0 \pm 9.04 \\
(\mathrm{~cm})\end{array}$ & $\begin{array}{c}13.38 \pm 36.15 \\
(\mathrm{~cm})\end{array}$ & & & \\
\hline & P.clarkii & & & 1,5 & 0.23 & 0.65 \\
\hline & Clutch density & $2.9 \pm 0.2$ & $0.4 \pm 0.02$ & 1,5 & 0.43 & 0.54 \\
\hline \multirow[t]{3}{*}{ Water depth } & & $\begin{array}{c}21.7 \pm 14.8 \\
(\mathrm{~cm})\end{array}$ & $\begin{array}{c}17.2 \pm 9.2 \\
(\mathrm{~cm})\end{array}$ & & & \\
\hline & P. clarkii & & & 1,5 & 0.06 & 0.81 \\
\hline & Max. pond depth & 60 & $64.19 \pm 1.9$ & 1,5 & 0.43 & 0.54 \\
\hline \multirow[t]{3}{*}{$\begin{array}{l}\text { Distance from the } \\
\text { shore }\end{array}$} & & $\begin{array}{l}95.1 \pm 125.4 \\
(\mathrm{~cm})\end{array}$ & $\begin{array}{c}95.4 \pm 128.7 \\
(\mathrm{~cm})\end{array}$ & & & \\
\hline & P. clarkii & & & 1,5 & 0.01 & 0.91 \\
\hline & Clutch density & $2.9 \pm 0.2$ & $0.4 \pm 0.02$ & 1,5 & 0.77 & 0.42 \\
\hline
\end{tabular}

1

\begin{tabular}{|c|c|c|c|c|c|c|}
\hline \multirow[t]{3}{*}{ Dependent } & \multirow[t]{3}{*}{ Independent } & \multicolumn{5}{|c|}{ Rana dalmatina } \\
\hline & & Without crayfish & With crayfish & df & $\mathrm{F}$ & $P$ \\
\hline & & Mean & Mean & & & \\
\hline \multirow[t]{3}{*}{ Interclutch distance } & & $\begin{array}{c}87.0 \pm 62.3 \\
(\mathrm{~cm})\end{array}$ & $\begin{array}{c}26.0 \pm 48.9 \\
(\mathrm{~cm})\end{array}$ & & & \\
\hline & P.clarkii & & & 1,10 & 1.51 & 0.25 \\
\hline & Clutch density & $0.7 \pm 0.01$ & $0.6 \pm 0.06$ & 1,10 & 0.79 & 0.21 \\
\hline Water depth & & $\begin{array}{l}19.7 \pm 7.8 \\
\quad(\mathrm{~cm})\end{array}$ & $\begin{array}{l}20.9 \pm 9.4 \\
\quad(\mathrm{~cm})\end{array}$ & & & \\
\hline \multirow[t]{3}{*}{$\begin{array}{l}\text { Distance from the } \\
\text { shore }\end{array}$} & & $\begin{array}{l}168.7 \pm 171.2 \\
(\mathrm{~cm})\end{array}$ & $\begin{array}{l}117.1 \pm 189.5 \\
(\mathrm{~cm})\end{array}$ & & & \\
\hline & P. clarkii & & & 1,10 & 0.25 & 0.63 \\
\hline & Clutch density & $0.7 \pm 0.01$ & $0.6 \pm 0.06$ & 1,10 & 1.71 & 0.22 \\
\hline
\end{tabular}




\section{Table 2 (on next page)}

Clutch microhabitat features and abundance of crayfish.

Clutch microhabitat features and effects of the relative abundance of crayfish for each species. Mean values for each microhabitat features are expressed in $\mathrm{cm} \pm \mathrm{SD}$. 


\begin{tabular}{|c|c|c|c|c|c|c|}
\hline \multirow[t]{3}{*}{ Dependent } & \multirow[t]{3}{*}{ Independent } & \multicolumn{5}{|c|}{ Rana latastei } \\
\hline & & Without crayfish & With crayfish & df & $\mathrm{F}$ & $P$ \\
\hline & & Mean & Mean & & & \\
\hline \multirow[t]{3}{*}{ Interclutch distance } & & $\begin{array}{l}10.0 \pm 9.04 \\
\quad(\mathrm{~cm})\end{array}$ & $\begin{array}{c}13.38 \pm 36.1 \\
(\mathrm{~cm})\end{array}$ & & & \\
\hline & CPUE & & & 1,5 & 3.40 & 0.12 \\
\hline & Clutch density & $2.9 \pm 0.2$ & $0.4 \pm 0.02$ & 1,5 & 1.21 & 0.32 \\
\hline \multirow[t]{3}{*}{ Water depth } & & $\begin{array}{l}21.7 \pm 14.8 \\
\quad(\mathrm{~cm})\end{array}$ & $\begin{array}{l}17.2 \pm 9.2 \\
\quad(\mathrm{~cm})\end{array}$ & & & \\
\hline & CPUE & & & 1,5 & 0.05 & 0.82 \\
\hline & Max. pond depth & 60 & $64.19 \pm 1.9$ & 1,5 & 0.18 & 0.68 \\
\hline \multirow[t]{3}{*}{$\begin{array}{l}\text { Distance from the } \\
\text { shore }\end{array}$} & & $\begin{array}{l}95.1 \pm 128.7 \\
(\mathrm{~cm})\end{array}$ & $\begin{array}{c}95.4 \pm 125.4 \\
(\mathrm{~cm})\end{array}$ & & & \\
\hline & CPUE & & & 1,5 & 1.10 & 0.34 \\
\hline & Clutch density & $2.9 \pm 0.2$ & $0.4 \pm 0.02$ & 1,5 & 1.42 & 0.28 \\
\hline
\end{tabular}

1

\begin{tabular}{|c|c|c|c|c|c|c|}
\hline \multirow[t]{3}{*}{ Dependent } & \multirow[t]{3}{*}{ Independent } & \multicolumn{5}{|c|}{ Rana dalmatina } \\
\hline & & Without crayfish & With crayfish & df & $\mathrm{F}$ & $P$ \\
\hline & & Mean & Mean & & & \\
\hline \multirow[t]{3}{*}{ Interclutch distance } & & $\begin{array}{c}87.0 \pm 62.3 \\
(\mathrm{~cm})\end{array}$ & $\begin{array}{c}22.5 \pm 42.8 \\
(\mathrm{~cm})\end{array}$ & & & \\
\hline & CPUE & & & 1,9 & 3.10 & 0.11 \\
\hline & Clutch density & $0.7 \pm 0.01$ & $0.6 \pm 0.06$ & 1,9 & 0.04 & 0.83 \\
\hline Water depth & & $\begin{array}{l}19.7 \pm 7.8 \\
\quad(\mathrm{~cm})\end{array}$ & $\begin{array}{l}21.3 \pm 9.3 \\
\quad(\mathrm{~cm})\end{array}$ & & & \\
\hline \multirow[t]{3}{*}{$\begin{array}{l}\text { Distance from the } \\
\text { shore }\end{array}$} & & $\begin{array}{l}168.7 \pm 171.2 \\
(\mathrm{~cm})\end{array}$ & $\begin{array}{l}117.7 \pm 191.5 \\
(\mathrm{~cm})\end{array}$ & & & \\
\hline & CPUE & & & 1,9 & 0.77 & 0.40 \\
\hline & Clutch density & $0.7 \pm 0.01$ & $0.6 \pm 0.06$ & 1,9 & 2.28 & 0.16 \\
\hline
\end{tabular}

